\title{
Problematiziranje relativizma u povijesnom, ali i suvremenom kontekstu
}

\author{
Zdravko Perić*
}

\begin{abstract}
Sažetak
Obzirom na pojavu većeg broja filozofske literature u kojoj se tematizira i podupire relativizam reagirao je prethodni papa Benedikt XVI. nazvavši ga diktaturom relativizma. Tim je stavom motivirao mnoge filozofe, teologe $i$ znanstvenike da iznesu svoje mišljenje o suvremenom relativizmu. Autor u prvom dijelu ovoga rada pokazuje neke specifičnosti najistaknutijih starogrčkih filozofa i njihov odnos spram relativizma. No, kako se relativizam pojavljivao, u različitim je vremenskim epohama različito bio tretiran. $U$ drugom dijelu rada naglašena je osebujnost, izvori i značenje suvremenog relativizma u današnjem svijetu. Tu se problematizira relativizam kroz radove najeminentnijih antropologa i filozofa koji su dali doprinos u afirmiranju i nijekanju relativizma. Autor na kraju donosi zaključak da relativizam ne može biti konačan u rješavanju međuljudskih problema jer postoje opća $i$ apsolutna rješenja koja vrijede uvijek $i$ svuda. U tom smislu relativizam može derogirati društvene, a i osobne vrijednosti temeljene na nepromjenljivim vrijednostima ljudske naravi koja se ne mijenja.

Ključne riječi: ironija, relativizam, ljudska narav, nepromjenljive vrijednosti, kultura
\end{abstract}

\section{Uvod}

Kako god promatrali ljude različitih vremenskih epoha u svojim specifičnostima i svojim osebujnostima bez obzira na vremensku distancu življenja, neka uvjerenja i neki stavovi jednostavno se ponavljaju i tiču se gotovo svih ljudi. Tu prvenstveno mislim na relativističko shvaćanje kako ništa ne vrijedi apsolutno i nužno, nego tek u odnosu prema nečemu drugomu. Taj relativistički svjetonazor predstavljao je velik problem kako za stare Grke tako i za suvremeni svijet u kojem živimo. Možda netko može pitati zašto su naši pape, posebice prethodni papa Benedikt XVI., zauzeli tako jasan i nedvojben stav protiv relativizma, govo-

* Dr. sc. Zdravko Perić, Filozofski fakultet Sveučilišta Josipa Jurja Strossmayera u Osijeku. Adresa: Lorenza Jägera 9, 31000 Osijek, Hrvatska. E-pošta: zperic@ffos.hr 
reći o diktaturi relativizma. ${ }^{1}$ Nije slučajno papa Benedikt XVI. zauzeo takav stav. Još kao kardinal govorio je o nadasve opasnoj i pogibeljnoj diktaturi relativizma, koja preuzima kormilo suvremenog svijeta i vodi ga prema krajnje opasnim područjima i sablažnjivim situacijama. Papa Benedikt XVI. prepoznao je u relativizmu ključ duboke krize našeg vremena.

Ključna rasprava našega vremena nije političke ili ekonomske naravi, nego kulturna, moralna te, u konačnici, religiozna. Riječ je o sukobu između dvaju pogleda na svijet: onoga koji vjeruje u postojanje načela i nepromjenjivih vrjednota, koje je Bog upisao u ljudsku narav, te onoga koji smatra da ne postoji ništa čvrsto i trajno, nego da je sve relativno s obzirom na vrijeme, mjesta i okolnosti. Ako ne postoje apsolutne vrjednote i objektivna prava, ljudski se život svodi na grozničavu potragu za užitcima te na egoistično zadovoljavanje instinkata i subjektivnih potreba, prozvanih novim pravima. ${ }^{2}$

Tim je stavom prethodni papa Benedikt XVI. pokazao kompleksnost problema koji nije samo aktualno vjerski problem. Raznovrsnost relativizma danas je toliko široka pa je teško dati jedan suvisao pregled njegova pojavljivanja. Papa se zalagao za dignitet ljudskog života, zaštitu svih prava osoba i obitelji, izgradnju pravednog i solidarnog svijeta, međureligijski i međukulturni dijalog. No, osim toga, za pretpostaviti je da papa Benedikt XVI. uviđa sve učestaliju pojavu suvremene literature koja podržava relativizam te stoga osjeća odgovornost da potakne suvremeni svijet na razmišljanje i konzekvence koje izaziva suvremeni relativizam. Dovoljno je spomenuti samo neke od tih knjiga koje tematiziraju problematiku relativizma: Oded Balaban, Plato and Protagoras, Trut and Relativism in Ancient Greek Philosophy, Steven D. Hales, Relativism and the Foundations of Philosophy, F. F. Centore, Two views of virtue. To su samo neke od brojnih knjiga koje su se pojavile neposredno prije ili poslije nego što je papa Benedikt XVI naglasio opasnost od relativizma nazvavši ga »diktaturom relativizma«. Među filozofima malo je onih koji će za sebe kazati da su relativisti, a ipak relativizam se neprestano pojavljuje u različitim oblicima. ${ }^{3}$ Neil Levy u svojoj knjizi Moralni relativizam piše: »Moralni relativizam, kao doktrina, ima pristaše daleko izvan granica filozofije. Možemo ga pronaći u sociologiji, povijesti i antropologiji (koju bismo mogli smatrati njegovim duhovnim domom), psihologiji i mnogim drugim znanstvenim disciplinama. $\ll^{4}$

Nadalje, N. Levy upozorava na utjecaj koji će relativizam imati u širem značenju: »Mnogo važnije će biti implikacije izvan akademskih granica, implikacije

1 Ivan Macan, Vlada li danas diktatura relativizma?, Obnovljeni život 62 (2007.) 1. str.1: »Relativizam se (...) pokazuje kao jedno stajalište koje odgovara današnjem vremenu. Stvara se dakle diktatura relativizma u kojoj se dakle ništa ne priznaje kao konačno i koja za posljednje mjerilo dopušta samo vlastitu osobu i njezine želje.«

2 Ta se misao nalazi na poleđini korica knjige Roberto de Mattei, Diktatura relativizma, Split, 2010.

3 Paul O'Grady, Relativism, Stocksfield, 2002, 3: »Hardly any philosopher wants to be called a relativist; nearly everyone is against it - whatever it is. Even those who are regarded by their fellow philosophers as archetypal relativists vigorously deny that they are relativists and indeed launch strong attacks on what they see as relativism."

4 Neil Levy, Moralni relativizam, Zagreb, 2004, 10. 
po naše svakodnevne živote i našu politiku, po načine poželjnoga pojedinačnog i kolektivnog ponašanja. $\ll^{5}$

Iako Levy ukazuje na moguće implikacije relativizma po naše svakodnevne živote, u svojoj prethodno navedenoj knjizi ne pokušava dokinuti relativizam, nego iznosi činjenice za i protiv relativizma. Kao konačno rješenje nudi pluralističku demokraciju koja bi trebala biti jamac međuljudskih odnosa. Taj je Levyjev koncept pluralizma neuvjerljiv. Njegov pluralizam ipak završava kao oblik relativizma za koji on kaže: »Stoga ne vidim razloga zašto ne bismo zaključili da pluralizam jest vrsta relativizma. Štoviše, mogla bi biti riječ o najplauzibilnijoj vrsti relativizma. $\ll^{6}$

Levy otvara relativizmu prostor na sofisticiran način tim što, proklamirajući vrijednost pluralizma, taj pluralizam kasnije izjednačava s relativizmom. Na početku knjige Relativism and the Foundations of Philosophy Steven D. Hales, ne krijući nikakve ambicije u afirmaciji relativizma, zagovara: »Ova je knjiga obrana relativizma. $\ll^{7}$

U toj knjizi Hales pristupa relativizmu kao glavnomu i fokalnomu problemu filozofije. Fokusira se na filozofske propozicije u analitičkoj filozofiji kao relativno istinite u nekim perspektivama, a u drugim perspektivama neistinite. Takav stav argumentirao je ispitujući racionalnu intuiciju koja mu služi kao metoda za filozofska vjerovanja prihvaćena od strane filozofa. Osim tih tvrdnji pomoću metode racionalne intuicije dolazi do osnovnih vjerovanja:

Ja sam uvjeren u argumente koji iznose istinu o tome što su moje moralne dužnosti. Postojanje i priroda Boga, priroda umjetnosti, analiza znanja i ostalo su samo relativne istine. To je gorka pilula koju smo progutali radi intelektualne iskrenosti... Krajnje je vrijeme da filozofi shvate kako njihove poznate osnove nemaju privilegiju i njihovo znanje nema monopol na istinu. Doista razlog tomu je tako što ne postoji jedna istina već više ovisnih istina. Relativizam proizlazi iz samog temelja filozofije. ${ }^{8}$

Relativizirajući gotovo sve što se može relativizirati, Steven D. Hales relativizira ona stajališta $\mathrm{i}$ istinu do koje je nekim od najvećih filozofa stalo pokazati istinitim, a ne relativnim.

\section{Ironija i relativizam}

Zanimljivo je osvrnuti se na tezu Stevena D. Halesa kojom tvrdi da relativizam proizlazi iz samog temelja filozofije. Na neki način s tom se tezom možemo složiti, ali važno je to da je relativizam u filozofiji i u njezinim temeljima prisutan kao problem koji treba stalno i iznova pobijati na način kako su to radili najistaknutiji grčki filozofi suprotstavljajući filozofiju sofistici. Jedan od najvećih starogrčkih filozofa, koji je velik dio svojeg filozofskog opusa izgradio suprotstavljajući se

5 Isto, str. 10.

6 Isto, str. 167.

7 Steven D. Hales, Relativism and the Foundations of Philosophy, Cambridge, 2006. 1.

8 Isto, str. 184-185. 
relativizmu, je Platon. Dovoljno je prisjetiti se samo nekih njegovih dijaloga u kojima piše i suprotstavlja svoj nauk sofističkomu: Sofist, Protagora, Gorgia, Theetet, Kritija, a i u drugim dijalozima, što implicitno, a što eksplicitno svoje mišljenje suprotstavlja sofističkomu. Koliko su god neki predsokratici značili i utjecali na Platonovo mišljenje, tu se prije svega mogu navesti Heraklit i Parmenid, njima Platon ne posvećuje ni približno prostora u svojim dijalozima koliko je napisao o pobijanju relativizma i sofistike. Na tragu Parmenida napisao je jedan od svojih najkompleksnijih dijaloga, dok Heraklitu nije posvetio nijedan konkretan spis, nego ga više sporadično koristi u svojim djelima. Platon je filozofiju shvaćao kao razotkrivanje i traganje za istinom i znanjem, a sofistiku kao privid, nešto što zamagljuje istinu. U dijalogu Sofist Platon je o sofistu napisao:

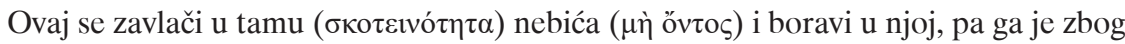

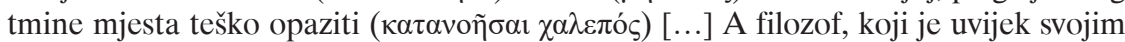
umovanjem privržen ideji bića, opet se zbog sjaja mjesta ne može nipošto lako opaziti

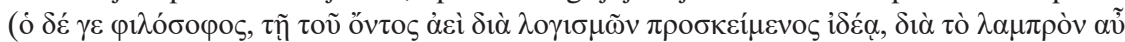

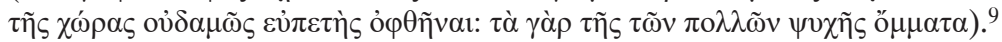

To je svakako zanimljivo mjesto u Platonovu Sofistu, gdje se na metaforičan način potencira distinkcija između filozofa i sofista. Filozof se kreće i pokazuje u svjetlu, a sofist se skriva i djeluje iz tame. Tu Platon karakterizira sofistiku kao deficijenciju ( $\left.\delta \delta^{\xi} \alpha\right)$ kojoj namjera nije participirati u biću, nego na nebiću ( $\mu$ ̀̀ ळv) što implicira neimanje udjela u biti bitka kao osnovnom pojmu filozofije. Naša je intencija u ovom poglavlju pokazati metodu kojom su se Platon i Sokrat suprotstavljali sofističkomu relativizmu. Platonov Sokrat i Sokratova ironija, koju mnogi interpreti spominju a ne objašnjavaju njezino značenje, može biti primjer za pristup relativizmu. Kod uporabe ironije značajan je pristup i identifikacija s tekstom iliti hermeneutički pristup. Lako se može prihvatiti tvrdnja da ono što autor piše nije ono što autor misli i zastupa. Poznati interpret Platonovih tekstova Gregory Vlastos u svojoj knjizi Socrates: Ironist and Moral Philosopher piše o dvije vrste ironije, jednostavnoj i složenoj: »Jednostavna ironija znači, ono što je kazano jednostavno nije ono što se misli da je. Dok u kompleksnoj ironiji ono što se kaže i je i nije ono što je pisac mislio. «10

Unatoč Vlastosovoj interpretaciji jednostavne i kompleksne ironije, smatramo da ne treba nužno slijediti njegovu podjelu ironije. Na ironiju se trebamo referirati samo onda kad je ona evidentno prisutna i prepoznatljiva čitateljima. Primjerice u dijalogu Protagora Sokrat kaže:

Kad on to reče, prisutni vikom pohvale da dobro govori. I ja rekoh. Protagoro ja sam slučajno zaboravljiv čovjek te zaboravljam o čemu je bio govor ako mi tko drugi

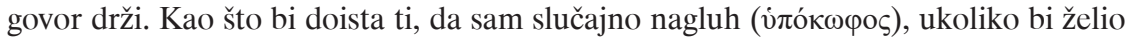

9 Platon, Sofist, 254a. (U članku sam se služio sljedećim prijevodima Platonovih dijela na hrvatski jezik: Platon, Sofist, (prev. Milivoj Sironić), Zagreb, 1975; Platon, Protagora (prev. Koloman Rac), u: Platon, Protagora; Sofist, Zagreb, 1975; Platon, Teetet, (prev. Miroslav Sironić i Veljko Gortan), Zagreb 1979.)

10 Gregory Vlastos, Socrates Irony, u: Essays on the Philosophy of Socrates, Oxford, 1992, str. 71. (prev. autor članka) 


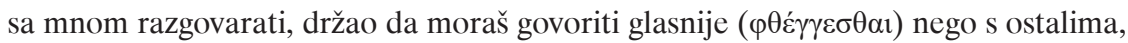
tako i sada, jer si se namjerio na zaboravna, steži mi i skraćuj odgovore ako hoćeš da

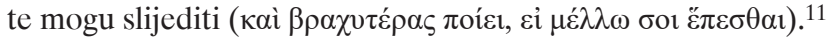

Iz samog navoda vidljiva je Sokratova ironija, koja ima metodski značaj pojednostavljivanja kompleksnih rečenica na jednostavnije i razumljivije rečenice. Sebe naziva zaboravljivim čovjekom, govori o sebi hipotetično kao slučajno nagluhom, traži od Protagore kratke rečenice. Netko bi mogao pomisliti radi Sokratovih zahtjeva za kratkim rečenicama da je prijepor o retoričkom nesuglasju, a mišljenja smo da je Sokratova namjera prisiliti Protagoru da govori kratko radi jasnoće $\mathrm{i}$ istinitih tvrdnji. Sokrat zastupa uporabu kratkih rečenica jer razgovor želi svesti na dijalošku formu u kojoj se može lakše doći do istine, a isto-

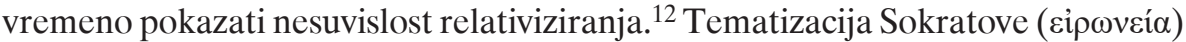
ironije izazivala je prijepore među mnogim misliocima. Primjerice, Melissa Lane navodi nekoliko značajnih autora koji su dali svoje mišljenje o ironiji. Tako kaže za Lea Straussa: »Sokratova ironija nije samo graciozan način govora. Ona je osmišljena kako bi njegove misli razumjeli samo neki, i da štiti njegov nauk od onih koji nisu sposobni razumjeti ironiju i filozofiju koju on promiče. «13

Dok Strauss vidi ironiju kao zaštitu Sokratove filozofije od onih koji je ne mogu razumjeti, a koji bi ju mogli krivo shvatiti i prikazati, neki je autori različito interpretiraju. ${ }^{14}$ Danas prevladava mišljenje da je Sokratova ironija uglavnom konstitutivnog dijalektičkog i argumentacijskog značenja. Sokrat i Protagora utvrdili su da percepcija (aisthêsis) nije znanje jer je nepostojana. Sokratova interpretacija Protagorine riječi: »Kakve se sve stvari meni čine, takve za mene i jesu, a kakve se tebi čine, takve su opet za tebe. Čovjek si naime i ti i ja. ( $\dot{\omega} s$

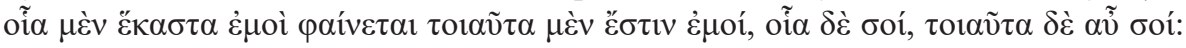

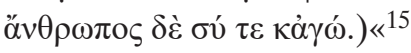

Taj navod može zavaravati svojom jednostavnošću. Tu nije riječ samo o subjektivnom doživljaju. ${ }^{16}$ Napor koji pokazuju obojica ilustrira fenomenološku stvarnost koja ne prelazi sadržajne okvire perceptivne tematizacije. No, i dalje je teško iz navoda vidjeti kako bi mogla ne biti jedna apsolutna činjenica o svijetu

11 Platon, Protagora, 334d.

12 Usp. Oded Balaban, Trut and Relativism in Ancient Greek Philosophy, Boston, 1999, 15-17.

13 Melissa Lane, Reconsidering Socratic Irony, u: The Cambridge Companion to Socrates, New York, 2011. str. 242.

14 Isto, 243. Melisa Lane u svojem radu navodi mišljenja autora koji ironiju povezuju sa Sokratovom egzaltacijom i egoizmom, tj. nemogućnošću da Sokrat eksplicira svoje misli. Nietzsche smatra Sokratovu ironiju kao intelektualnu nemogućnost argumentacije njegovih stavova. Kierkegaard smatra da granica Sokratove ironije omogućuje skok u religijsko vjerovanje.

15 Platon, Teetet, 152a.

16 Isto, 152c. Pojava, dakle i percepcija, kod toplog i svega takvog je jedno te isto (phantasia ara kai aisthêsis tauton en te thermois kai pasi tois toioutois). Kako, naime, svako osjeća tako se i svakomu čini da jest (hoia gar aisthanetai hekastos, toiauta hekastô(i) kai kinduneuei einai). Percepcija se, dakle, uvijek odnosi na biće i nije neistinita ako je znanje (aisthêsis ara tou ontos aei estin kai apseudes hôs epistêmê ousa). 
unatoč različitim interpretacijama. ${ }^{17}$ Smisao započinjanja takve naizgled naivne tematizacije uvod je u ontološku eksplikaciju koja pitanjem o stvarnosti svijeta nameće tezu o istini $\dot{\alpha} \lambda \eta \dot{\theta} \theta \varepsilon ı \alpha$ ili o mjernom standardu. Sokratu znanje $\dot{\varepsilon} \pi \iota \tau \eta \dot{\mu \eta}$ znači spoznaja općega koje ima osebujna svojstva:

Zar se dakle i tebi čini tako o spoznaji ili je ona krasna i vrsna vladati čovjekom, pa spoznaje li tko dobro i zlo, neće ga ništa svladati da bi nešto drugo radio negoli

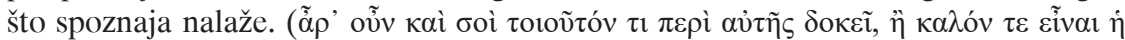

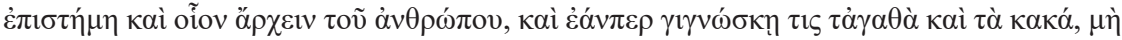

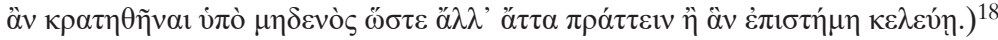

Budući da su utvrdili da se pojavom ne može doći do znanja, Sokrat i Platon prihvatili su teoriju mjere kao supstituciju za pojavnost. Protagora je jedno svoje djelo naslovio Istina ('A $\lambda \hat{\eta} \theta \varepsilon 1 \alpha$ ). U tom djelu znakovita je njegova izreka: »Čovjek je mjerilo svih stvari: onih koje jesu da jesu, a onih koje nisu da nisu. ( $\pi \alpha ́ v \tau \omega v$

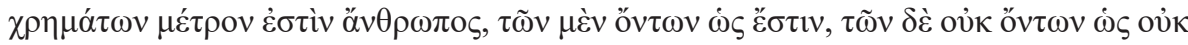
$\varepsilon \check{\sigma \tau \tau \imath .)} \ll^{19}$

Iz takve relativističke tvrdnje, koja je u suprotnosti s naslovom spomenutog djela, nametnulo se pitanje: ako je čovjek mjera svih stvari, što je čovjek? Tu bi svaki pojedini čovjek za sebe pretpostavljao svoju stvarnost, svoj svijet. Sokrat se ponovno ironijom suprotstavio Protagorinu antropocentrizmu:

$\mathrm{Na}$ početku njegova razlaganja začudio sam se, tj. da u početku svog spisa Istina nije rekao. Mjera svih stvari je svinja ili majmun ili neko drugo bezumno stvorenje koje

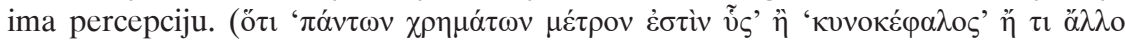

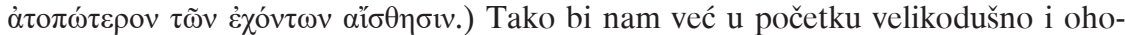
lo govorio dokazujući da upravo pameću ne samo da nije ništa bolji od bilo kojeg

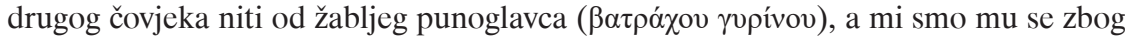
mudrosti divili kao bogu. ${ }^{20}$

Postaviti mjernu doktrinu u individualne osobe znači razdijeliti standard na subjektivna određenja. Sokrat se opet poslužio ironijom spominjući svinju i majmuna u namjeri da pokaže nesuvislost Protagorine tvrdnje. Suprotstavljajući se Protagorinu relativizmu, Sokrat je jednostavno branio svoju dijalektičku metodu koja je bila na velikim iskušenjima. U 19. stoljeću neki su interpreti pokušali zatomiti Protagorin relativizam tumačeći čovjeka ( $\alpha v \theta \rho \omega \pi \mathrm{s})$ kao humano socijalno, a ne individualno biće. U tom slučaju čovjek bi bio prikazan kao vrsta, a stvari koje nam se prikazuju bile bi sukladne čovjekovoj naravi. Platonova deskripcija Sokrata i njegov misaoni diskurs ostavljaju mogućnost mnogovrsnim spekulacijama. No, činjenica je da Sokrat nije bio varalica i u želji da pobjedi sugovornika nije koristio ironiju kao sredstvo prijevare, nego mu je ironija služila za postizanje onog zajedničkog temelja (sensus communisa) kako bi mogli suvislo zdravorazumski dijalogizirati. Puno je puta samog sebe ironično derogirao

17 Usp. David Sedley, The Midwife of Platonism, New York, 2004, 47.

18 Platon, Protagora, 352c.

19 Platon, Teetet, 152a.

20 Platon, Teetet, 161d. 
pozicionirajući se inferiornim spram drugog sugovornika. Često je puta konverzacija - diskusija bila moguća između Sokrata i njegovih oponenata samo ako su njegovi sugovornici prihvatili pravila diskusije i mogli demonstrirati svoju superiornost nad Sokratom. U tom konstitutivnom retoričkom smislu možemo promatrati Sokratovu ironiju koju on koristi protiv relativizma. Prema Platonu, relativizam je produkt čovjekova neznanja i oholosti. Svaki onaj koji je realan morao bi znati da je svijet puno više od toga što mi o njemu znamo. Oholost proizvodi alijenaciju i egoizam, što je pogubno za ljude. Zato se Platon usmjerio na objektivno znanje jer ono daje sigurnost koja je izražena kao vedrina, zadovoljstvo i smijeh.

\section{Ishodište suvremenog relativizma}

Moderna, a i suvremena filozofija svoje ishodište uglavnom pronalazi u filozofiji Renéa Descartesa (1596.-1650.). Descartesov racionalizam, sa svojim zahtjevom za nepokolebljivim znanjem i univerzalnim konceptom uporabe razuma, nije sam po sebi kreirao puno prostora za relativizam. ${ }^{21}$ Jednom kad su razum i racionalnost prihvaćeni kao univerzalne metode za otkrivanje istine, razum se afirmira kao nužnost bez alternative: »Descartes je vjerovao u postojanje jednakog razuma kod svih ljudi; iako se razum pojavljuje varijabilno zbog činjenica da ga neki pojedinci koriste mudro a drugi ne. $\ll^{22}$

Znanstvena je revolucija kroz radove Copernicusa, Galilea, Keplera, Bacona, Hobbesa i Descartesa nametnula novo razumijevanje stvarnosti. U stvari, znanstvena metoda koju su ustanovili spomenuti mislitelji omogućila je da se znanje stječe otkrivanjem činjenica neovisno o nama samima. Descartes je svojim dualizmom podijelio stvarnost na unutarnju i vanjsku, tj. subjektivnu i objektivnu. Svojom maksimom cogito ergo sum poimanje istine prebacio je na subjektivni teren ljudskog razuma. Za njega je istina samo ono što se može spoznati clare et distincte. Descartesov ego postao je spoznajni autoritet za izvor subjektivnog opisa svijeta, što je samo po sebi nametnulo vjerodostojnost individualnog stajališta pojedinca kao valjanu osnovu spoznaje. Načelo emancipirane subjektivnosti i čovjekove autonomije sapere aude potvrdio je i Kant. U svojim je kritikama Kant uzdignuo um na najviše kritičko sudište, a sve što pretendira na istinitost i valjanost mora se moći opravdati pred tim najvišim sudištem. ${ }^{23}$ Pun učinak i posljedice Descartesove filozofske podjele na subjekt i objekt postaju jasne tek s pojavom romanticizma u 19. stoljeću. Naime, romanticizam razum podređuje maštovitosti, kreativnosti i osobnim aspektima ljudskoga uma. »Descartov filozofski pristup podijeljenosti na subjektivnost i objektivnost motivirao je relativističko gledište u filozofiji. ${ }^{24}$

21 Maria Baghramian, Relativism, London, 2004, 41.

22 Isto, 248.

23 Usp. Stipe Tadić, Jedna i/ili više istina, u: Diktatura relativizma, Zagreb, 2009, 84-85.

24 Maria Baghramian, Relativism, 42. 


\section{Suvremeni relativizam}

Velik dio suvremenog intelektualnog etosa oblikovan je pod utjecajem relativizma. Još je tijekom 1950. godine održano više popularnih rasprava o opsegu i zahtjevima ćudoređa. Posljedica tih rasprava bila je proklamacija moderne apsolutne relativnosti kao vrijednosti, a stari moral trebao je biti potisnut. Norman je Mailer pisao:

Osobnosti...ulaze tiho u apsolutnu relativnost gdje nema istine osim zasebnih istina koje svaki promatrač osjeća u svakom trenutku svojeg života... Posljedica toga je rastajanje čovjeka od vlastitih vrijednosti, oslobađanjem svojeg jastva od društvenog Superega. Samo moderni moral zna ono što pojedinac osjeća i može... a to znači otvoriti granice mogućeg za sebe, za sebe sama jer to je ono što pojedinac treba. ${ }^{25}$

Proces sekularizacije u Europi u 19. stoljeću započinje na znanstvenom polju. Darwinova teorija evolucije pokušala je oslabiti ljudska vjerovanja u biblijska poimanja svijeta i stvarnosti. T. H. Huxley, vatreni prozelit Darwinove revolucionarne ideje, kreirao je pojam agnosticizma kojim je uspio pridobiti intelektualni sentiment, čest pojam 20. stoljeća. Suvremeni mislioci pronalaze u djelima socijalnih antropologa najutjecajniji oblik potpore suvremenomu relativizmu. Etnografski podatci koje pronalaze socijalni antropolozi navode se često kao potpora za objašnjenje razlika u vjerovanjima i kulturama.

Njihova empirijska zapažanja često podržavaju kulturni relativizam, što nije ništa drugo nego načelo po kojem nema univerzalne istine. Prema kulturnom relativizmu istina se razlikuje od osobe do osobe, ovisno o načinu tumačenja iskustva s obzirom na podrijetlo, vrijednosti i socijalne norme. Ti čimbenici utječu na percepciju i procjenu, tako da nema jedinstvene ljestvice vrijednosti za sva društva. Kulturni relativisti jednako vrednuju sve poglede na svijet. Za njih je istina relativna, ovisno o podrijetlu pojedinca, njegovu kulturnom identitetu i okolini. Sve važnije dimenzije ljudskog iskustva, uključujući moralnost i etiku, za njih su više lokalne i promjenljive nego univerzalne. Od istaknutijih zagovornika tog relativizma bili su R. Benedict i M. J. Herskovits. O kulturnom je relativizmu Herskovits pisao:

Pristupiti pitanju o prirodi i ulozi vrednota u kulturi predstavlja znanstveni induktivni napad na prastari filozofski problem. U te svrhe koriste se novi međukulturalni podatci koji do sada nisu bili dostupni znanstvenicima. Načelo kulturnog relativizma sažeto znači: Stavovi se temelje na iskustvu, a iskustvo tumači svaki pojedinac u smislu njegove vlastite enkulturacije. Čak i činjenice o fizičkom svijetu valja prosuđivati kroz enkulturalne zaslone (enculturative screen), tako da je percepcija vremena, udaljenosti, težine, veličine i druge stvarnosti posredovana konvencijama (mediated by the conventions) različitih grupacija. ${ }^{26}$

Argumenti za kulturni relativizam obično se temelje na deskriptivnoj pretpostavci. Empirijska promatranja pokazuju da postoji mnoštvo nekompatibilnih

25 John W. Cook, Morality and Cultural Differences, Oxford, 1999, 41. (prev. autor članka).

26 Melville J. Herskovits, Man and his works: The science of cultural anthropology, s.1., 1952, 61. 
i nepomirljivih svjetonazora i vrijednosnih sustava. Epistemološka pretpostavka kaže da ne postoji ni jedan pouzdani kriterij ili metoda rješavanja između oprečnih i nesumjerljivih svjetonazora te vrijednosnih sustava.

Normativna pretpostavka toleranciju i svjetonazor drugih kultura proklamira prihvatljivijim ne pokušavajući nametnuti svoje stavove drugim kulturama.

\section{Benjamin Lee Whorf $i$ Donald Davidson}

Potporu kulturnomu relativizmu možemo naći i u djelu Benjamina L. Whorfa. Njega suvremeni autori često navode kao locus classicus za pristup onomu što se zove lingvistički relativizam (linguistic relativity). Smatrao je proučavanje jezika najneposrednijim načinom razumijevanja ljudskog mišljenja:

Općenito, mišljenje je krajnje tajanstveno, a daleko najviše svjetla koje je bačeno na njega dobili smo proučavanjem jezika. To proučavanje pokazuje da su forme mišljenja bilo koje osobe kontrolirane putem nepopustljivih zakonitosti sistema obrazaca kojega ta osoba nije svjesna. Ti obrasci ne mogu pretpostaviti kompliciranu sistematizaciju njezina vlastitog jezika - koja se lako pokazuje u nepristranoj komparaciji sa suprotnostima drugih jezika, a pogotovo onim koji pripadaju drugim jezičnim porodicama. ${ }^{27}$

Whorfovo proučavanje američkih indijanskih jezika, naročito Hopi plemena, omogućio mu je osebujnu argumentaciju na koju će se pozivati mnogi:

Mi istražujemo prirodu na način kako su to oblikovali naši materinski jezici. Kategorije i tipove koje izdvajamo iz svijeta pojava ne nalazimo tamo zato što one odmah padaju u oči svakomu promatraču; upravo nasuprot tomu, svijet je predstavljen u kaleidoskopskom tijeku impresija (the world is presented in a kaleidoscopic flux of impressions), koje trebaju biti organizirane pomoću naše svijesti, a to znači uglavnom pomoću lingvističkog sustava u našoj svijesti (linguistic systems in our minds). Mi razvrstavamo prirodu, organiziramo je u pojmove i pripisujemo joj značenja na način na koji to radimo najvećim dijelom zato što sudjelujemo u sporazumu, čineći tako sporazum koji važi za cijelu našu govornu zajednicu i koji je kodificiran obrascima našeg jezika. ${ }^{28}$

Whorf je predložio novi princip relativnosti tvrdeći da svi promatrači nisu vođeni istim fizičkim dokazima koji bi ih trebali voditi do istih slika o svijetu, osim naravno ako njihove jezične pozadine nisu slične ili drugačije standardizirane. Takvo načelo jezične relativnosti dovodi do zaključka da pojedinci koji se koriste radikalno različitim jezicima žive u različitim svjetovima: »Korisnici izrazito različitih gramatika (markedly different grammars) u svojim su gramatikama naglasili drugačiji tip opservacija i drugačije vrednovanje izvanjsko sličnih djela (different evaluations of externally similar acts of observation), iako su različiti, moraju se moći dogovoriti o nekim različitim pogledima na svijet. $\ll^{29}$ 
Whorfov student Edward Sapir pokušao je biti još uvjerljiviji od svog učitelja: »Stvarni svijet je u velikoj mjeri nesvjesno izgrađen na jeziku navika skupine ( $h a-$ bits of the group). Ne postoje dva jezika s tolikom sličnošću koja bi predstavljala istu društvenu stvarnost. Svjetovi u kojima različita društva žive različiti su svjetovi. Mi vidimo i čujemo drugačije od drugih zato što su jezične navike naše zajednice predisponirane određenim izborom tumačenja. «30

Njegova lingvistika, naročito Sapir-Whorfova hipoteza, bila je inspirativna za druge suvremene relativističke stavove. Međutim, Whorf nije vjerovao da ce njegova lingvistička relativnost dovesti do neprevodivosti i nesumjerljivosti. Smatrao je da ne postoje znanstvenici koji mogu biti apsolutno nepristrani u određenju prirode jer smo svi mi ograničeni našim jezičnim podrijetlom. ${ }^{31}$ Prema Whorfu, svijest o jezičnoj relativnosti imat će pozitivnu posljedicu na nas same. Ta relativistička jezična posljedica trebala bi nas učiniti skromnijim i tolerantnijim u našim zahtjevima prema univerzalnosti spram naše znanosti i svjetonazora, ali ne bi loše utjecala na našu komunikaciju. Najvećim je dijelom Whorf bio kritiziran za nesumjerljivost. Kazati da su dva sustava standarda ili koncepta nesumjerljivi znači tvrditi da između njih nije moguća nikakva usporedba. Dva sustava koncepata nesumjerljivi su kada neke osnovne pojmove prvog sustava, ili čak nijedan, nije moguće ni izraziti jezikom drugoga. Oni jednostavno ne postoje u istom logičkom prostoru jer su strani jedan drugomu. Ako su dva sustava koncepata nesumjerljiva, nije moguće prosuditi o njihovoj relativnoj vrijednosti. Takvu ideju o nesumjerljivosti koncepata moguće bi bilo aplicirati u područje etike. Ideju nesumjerljivosti podvrgnuo je velikoj kritici suvremeni autor Donald Davidson. On je tvrdio u svojem eseju $O$ samoj ideji konceptualne sheme (On the Very Idea of a Conceptual Scheme) da bez obzira kako velik bio nesklad između dvaju jezičnih problema, u samoj osnovi postoji mogućnost dogovora o problemu nesuglasja. To znači da je i sama ideja o postojanju dva nesumjerljiva jezika ili sustava koncepata u sebi samoj nekoherentna. Kada se upuštamo u postupak prevođenja stranog jezika, pretpostavljamo da urođenici govore ono što žele. Pretpostavljamo da urođenici govore istinu. Kad ne bi bilo tako, ne bismo mogli započeti s Davidsonovom radikalnom interpretacijom. ${ }^{32}$ Ne možemo se upustiti u radikalnu interpretaciju ukoliko ljudi nisu konzistentni u načinu korištenja jezika. To podrazumijeva da se njihova uporaba jezika na neki način podudara s našom. Davidsonova radikalna interpretacija pretpostavlja prihvaćanje načela milosrđa (principle of charity). Jedna od najpotpunijih i najviše korištenih verzija je Michaela Scrivena, koja glasi:

Načelo milosrđa zahtijeva da podarimo prednost prije najboljoj, a ne najgoroj mogućoj interpretaciji materijala koji proučavamo. Načelo milosrđa je više od samog etičkog principa, ali je u najmanju ruku to. Ono zahtijeva da budeš pošten ili pravedan u

31 Osoba koja je najbliža slobodi u tom smislu, prema Whorfu, bio bi lingvist koji poznaje brojne različite jezične sustave. Usp. Language, Thought, and Reality, str. 214.

32 Usp. Donald Davidson, Inquiries into Truth and Interpretation, Oxford, 2001, 184. 
svojim kritikama. One mogu biti izražene na žustriji način, ukoliko je to primjereno; mogu uključivati zaključke o kompetenciji, intelektualnoj razini ili savjesti osobe koja je iznijela argument, a da pritom zaista budu opravdane u pojedinim slučajevima. ${ }^{33}$

Sada možemo iznijeti Davidsonov argument protiv postojanja nesumjerljivih konceptualnih shema. Iako su konceptualne sheme, a i one suprotstavljene našoj, inkorporirane u jeziku, jezici koji ih sadrže, ako one postoje, morali bi biti neprevodivi na naš jezik. Whorf je htio pokazati da je Hopi pleme u svoj jezik inkorporiralo neku čudnu metafiziku konceptualno različitu i neprevodivu na engleski jezik. ${ }^{34}$ Ono što uočava Davidson kod Whorfa je to da nam Whorf govori na engleskom jeziku što ti koncepti Hopi jezika izražavaju. Slično Whorfovoj konceptualnoj nesumjerljivosti nalazimo i primjer kod dugih autora: »T. Kuhn nam jasno ukazuje na to kako je stanje stvari bilo prije znanstvene revolucije, koristeći se — a čime drugim — našim post-revolucionarnim idiomom. «35

Riječ je na neki način o dominantnoj metafori konceptualnog relativizma, koja pokazuje pragmatički paradoks između toga što neki filozofi tvrde i onoga što njihovi osobni primjeri pokazuju. Posebnost njihove uspješnosti u prenošenju navodnog sadržaja neprevodivih shema koje prevode, odaje neistinitost njihove doktrine. Davidson je bio u suprotnosti s najeklatantnijim primjerima mišljenja što ih pristaše neprevodivosti mogu iznijeti. Smatrao je da se sadržaji tih tzv. nesumjerljivih jezika mogu prevesti na engleski jezik i bilo koji drugi prirodni jezik. Ako postoje neka glasovanja ili drugačija ponašanja nekih bića koja se ne mogu interpretirati na naš jezik, onda to nije jezik. ${ }^{36}$ Kada se susretnemo sa skupinom ljudi koji govore nekim jezikom, jedna od dvije stvari mora biti istinita: ili je jezik kojim govore moguće prevesti na naš ili taj jezik nije moguće prevesti na naš. U tom slučaju nemamo razloga smatrati da je uopće riječ o jeziku. Kulturni, konceptualni ili neki drugi suvremeni relativizam ima znatnih problema koherentno objasniti svoja stajališta.

\section{Umjesto zaključka}

Papa Benedikt XVI. ukazao je na pojavu sve većeg broja suvremene literature koja podržava relativizam nazvavši ga diktaturom relativizma. U relativizmu on je prepoznao ključ duboke krize suvremenog svijeta, te je stoga osjećao odgovornost da potakne suvremeni svijet na razmišljanje i konzekvence koje izaziva suvremeni relativizam. Osnovna značajka relativizma je to da se istina ne može utvrditi ili da postoji više istina. To dovodi do toga da pojedinci tvrde kako postojanje Boga, priroda i umjetnost, analiza znanja i ostalo samo su relativne istine, a s tim se ne možemo složiti. Benedikt XVI. zauzeo je jasan i nedvosmislen stav

33 John H. Woods, The Death of Argument: Fallacies in Agent-Based Reasoning, Dordrecht, 2004, 222.

34 Usp. Donald Davidson, Inquiries into Truth and Interpretation, 184.

35 Isto, str. 184.

36 Isto, str. $185-186$. 
protiv relativizma. On smatra da u današnjem vremenu postoji jaka tendencija nametanja jedne neodređene relativističke ideologije, kao današnje kulture. Takva relativistička kultura u osnovi zanemaruje i rastače onaj zajednički kršćanski temelj koji je bio vjekovima temelj suživota europskih naroda. U dokazivanju problema koje je relativizam nametnuo osvrnuo sam se na ishodišne probleme koji su se pojavili u antičkoj grčkoj filozofiji. Prije pape Benedikta XVI., kako je pokazano, relativizmu su se suprotstavili najveći grčki filozofi Sokrat, Platon i drugi suprotstavivši se sofistima. U svoju dijalektičku metodu Sokrat je umetnuo ironiju kao osebujan način pobijanja relativizma. Time je i nama pokazao jedan od načina kako se suprotstaviti relativizmu. Sokratova je ironija i danas u fokusu rasprava suvremenih filozofskih diskusija. Ironiju je Sokrat često koristio u dijalogu sa sofistima, ne zato da bi ih nužno pobijao u mišljenju. Njemu je ironija bila više metodičko sredstvo kako bi stvorio zajedničku osnovu dijaloga za postizanje univerzalnog cilja. Grčka filozofija, a nakon nje i kršćanstvo, prepoznali su prirodni zakon kao objektivni zakon upisan u samu ljudsku narav. Sveti ga je Toma Akvinski definirao kao sami vječni zakon utisnut u razumno stvorenje (Nihil est aliud quam participatio legis aeternae in rationali creatura. ${ }^{37}$ ) Prema Tomi Akvinskomu, ništa nije pravedno ukoliko ne proizlazi iz vječnog zakona. Relativizmu treba suprotstaviti jasno poimanje prava, koje pretpostavlja ispravno antropološko viđenje. Nije moguće temeljiti općenitost ljudskih prava izvan objektivne ljudske naravi koja je u sebi samoj stalna. Naravni zakon i prava koja iz njega proizlaze vječna su i nepromjenljiva, a vrijede za sva vremena i sve ljude. Ideja o postojanju jedne ljudske naravi obilježene trajnim i vječnim zakonom nastala je u filozofiji stare Grčke. Na toj se grčkoj ideji temeljilo rimsko pravo koje je ostalo arhetip svakoj pravnoj građevini koja je željela dugo trajati. Osim tih povijesnih aspekata o relativizmu, znatan dio rada posvećen je kulturnomu i lingvističkomu relativizmu. Primjerice Ruth Benedict pisala je o problemima kulturnog relativizma. Prema njoj kulturni relativizam implicira vrstu arbitrarnosti, ali i unosi dozu nelagode kod ljudi. ${ }^{38}$ Unoseći konfuziju u klasični moral, suvremeni relativizam stvara pesimističko ozračje jer ne daje jasnu sliku nove kulture i međuljudskih odnosa. Ono što primjerice R. Benedict ne kaže je, ukoliko bismo odbacili provjerene vrijednosti i prihvatili nove, na koji bi način te nove vrijednosti bile svrsishodnije od starih vrijednosti. Ne vidi se plauzibilna argumentacija koja bi kazala zašto bi netko trebao biti zadovoljan samo time što smo promijenili sustav vrijednosti koji je sam po sebi neizvjestan. Odgovor bi mogao u relativističkom trendu glasiti: zato što su sve kulture same po sebi jednako vrijedne. To je relativističko gledište, koje pokušava nametnuti pluralizam kao normu vrijednosti i krajnje rješenje u suvremenom demokratskom svijetu. Jedan od najpoznatijih jezičnih relativista B. L. Whorf kazao je da jezik stvara organizaciju iskustva. Whorf je tvrdio kako određeni jezik favorizira određeni način poimanja svijeta, odnosno određeni tip jezika uvjetuje određeni tip kulture. Najvećim dije-

37 Thomas Aquinas, Summa contra gentiles, lib. III, cap, CXIV-CXXVI.

38 Ruth Benedict, Patterns of Culture, New York, 1957, str. 278. 
lom Whorf je bio kritiziran za koncept nesumjerljivosti. To znači da između dva jezična standarda nije moguća nikakva usporedba. Oni jednostavno ne postoje $\mathrm{u}$ istom logičkom prostoru jer su strani jedan drugomu. Dva nesumjerljiva konceptualna sustava nije moguće prosuditi u njihovoj vrijednosti. Whorfov koncept nesumjerljivosti velikoj kritici podvrgnuo je Donald Davidson. On je smatrao da u samoj osnovi postoji mogućnost dogovora o problemu nesuglasja. Njegova radikalna interpretacija pretpostavlja prihvaćanje načela milosrđa, koje zahtijeva da podarimo prednost prije najboljoj, a ne najgoroj mogućoj interpretaciji materijala koji proučavamo. U današnjem dobu relativizam se pokazuje kao doktrina moderne liberalne filozofije koja bi trebala potisnuti Sokratovu i Platonovu filozofsku tradiciju. Sokrat i Platon bili su besprijekorni tražitelji istine koja ih je činila sretnima. Na njihovu tragu mi možemo konstatirati da je prihvatljivije vidjeti čovjeka kojemu oči sjaje od čiste radosti jer posjeduje istinu, nego nekoga neodređenog relativistu.

The Issue of Relativism in the Historical, but also Contemporary Context

\section{Zdravko Perić*}

\section{Summary}

Amassing philosophical literature on the topic of relativism and in support of it brought about a reaction on the part of the previous pope, Pope Benedict. His stance has motivated many philosophers, theologians and scholars to come forward with their opinions on contemporary relativism. The author illustrates, in the first section of this article, certain specificities of the most prominent philosophers of Ancient Greece and their approach to relativism. Still, as relativism emerged through the ages, so it was treated differently in each time period. The second section of the essay highlights the particularities, sources and significance of relativism in the world today. The author takes issue with relativism through the works of the most eminent anthropologists and philosophers who have made a contribution to either its affirmation or negation. Finally, the author concludes that relativism cannot have the ultimate say in solving human relationship problems for there exist general and absolute solutions which apply always and everywhere. Hence, relativism may derogate social, but also personal values that are based on the immutable values of human nature which is constant.

Key words: irony, relativism, human nature, immutable values, culture

* Zdravko Perić, Ph.D., Faculty of Philosophy. The Josip Juraj Strossmayer University of Osijek. Address: Lorenza Jägera 9, 31000 Osijek, Croatia. E-mail: zperic@ffos.hr 